\title{
THE IMPLEMENTATION OF MAKE A MATCH METHOD TO IMPROVE WRITING DESCRIPTIVE TEXT AT TENTH GRADE STUDENTS IN SMK JABIR AL-HAYYAN
}

\author{
Mahmud Yusuf ${ }^{1}$, Hasanudin $^{2}$ \\ ${ }^{1}$ IKIP Siliwangi \\ ${ }^{2}$ IKIP Siliwangi \\ ${ }^{1}$ mahmudkrollz199@gmail.com, ${ }^{2}$ hasanudinyki1@gmail.com
}

\begin{abstract}
Based on the phenomena that students have difficulties in writing descriptive text, the students could not write because do not have any ideas when they are asked to write. So, they need some ways which could help them in writing. The problems in writing can be solved by implementing some strategies in teaching writing. One of approach that teacher can use to help students write a good text is MAM. The main objective of this study is find out if MAM can improve students' ability in writing descriptive text. The research method used is quantitative research, specifically quantitative with one group pretestposttest design. The sample take two class at tenth grade students of SMK Jabir Al-Hayyan in academic year 2019/2020. The data had been obtained in post-test of experimental class were: the highest score was 96, the lowest score was 62 , and the mean score was 80.50 . Post-test of control class were: the highest score was 89 , the lower score was 60 , and the mean score was 71.54 . It can be seen from the data showed that students' score in experimental class was highest than control class. It means that using make a match method was effective, easier, and more understable to be applied in teaching and learning process, especially in writing descriptive text.
\end{abstract}

Keywords: Improve, Make A Match Method, Writing Descriptive Text

\section{INTRODUCTION}

In Indonesia, English language is very impotant because knowledge of English gives prestige as well as a means of personal advancement in professional and academic fields. According to (Santosa \& Andriyadi, n.d.) English is an important language to learn. Especially with the development of the increasingly demanding era of all people to be able to use English language so that increasing the English language is increasingly important to learn. In English, there are four skills that should be mastered, as follows : listening, speaking, reading, and writing. From the explanation above, the researcher chooses one of the four abilities, namely writing.

Writing is one of the important aspects in learning language, especially English. Brown (2004: 255) as cited in Yulianti, Nuraeni,n\& Parmawati (2019) state that "Writing is a process to create some ideas of students' knowledge to be a written".In real life, people cannot avoid the activity of writing. Writing can be found from many things in the daily life, for example, writing announcement in a school board, writing letters, texting message, e-mailing, and so on. Therefore, writing is needed and important to be learned by the students, especially in senior high school. Harmer (2004:31) in Siti \& Suprijadi, 2015) states "Writing encourage students to focus on accurate language use and because they think as they write, it will provoke language development as they resolve problems which the writing puts into their minds". In addition, Gebhard (1996) cited in Apsari (2018) describes that writing involves several components which have to be considered including word choice, use of appropriate grammar, syntax, 
mechanics, and organization of ideas into coherent and cohesive form. That statement shows that wrting is not a simple and instant process. therefore, to be able to write something good, students must do a lot of practices. it is done to get them used to write anything in the wellordered steps.

In fact, some pedagogic applications of genre analyses seem to be based on the notion of "text type" rather than "genre". Derewianka (1991) in Paltridege, 1996) For example, in her discussion of writing in schools, present as type text such as narrative text, recount text, procedure text, report text, descriptive text, exposition, explanation.

Descriptive text is the text that describes something. A descriptive text is designed to describe how something is achieved through a sequence of the object. This text uses the simple present tense, and the generic structure is identification and description. The researchers focuses on descriptive text. Wyrick (1987:227) in Lailatul Husna, Zainil, (2013) states, "The writer of description creates a word-picture of persons, places, objects, and emotions using a careful selection of detail to make an impression on the reader.

In teaching and learning process, the researcher using a media for teaching, namely make a match. That media can help the teacher offering learning material, it can make a stimulus of mind, sense, attention and will which can make effective learning process. While we are teaching in the class, it is important to make the class fun and active, by using make a match type of cooperative learning, we can make all of students in the class become more interactive and involving themselves into the class's activities. (Wastawan, Sutarsyah, \& Sudirman, 2014), states that this type can make the students' interest increase and interfere to the interactive situation in the class. It is why the teacher should use make a match type of cooperative learning to make the students easier to comprehend the text.

\section{METHOD}

The researchers uses quantitative method. This method get real data in the field. Aliaga, and Gunderson (2002) in (Apuke, 2017), describes quantitative research methods as the explaining of an issue or phenomenon through gathering data in numerical form and analyzing with the aid of mathematical methods; in particular statistics. The researchers use pretest, treatment and posttest for collecting data in order to know students thinking perceptions in writing descriptive text. Referred to collecting data, the researchers conducted population and sample of this research. The population of this research take the tenth grade students at SMK Jabir Al-Hayyan in academic year 2018/2019. In this study, the researchers took two classes of sample. Namely experiment class and control class which the total of sample was 34 students. In experimental class was 13 male students and 21 female students. The control class was 12 male students and 22 female students, so the total of both the class was 34 students.

\section{RESULTS AND DISCUSSION}

\section{Results}

Table 1. data of pretest and posttest

\begin{tabular}{cccccccc}
\hline & \multicolumn{2}{c}{ Experiment Class } & \multicolumn{5}{c}{ Control Class } \\
\hline No & Name & pretest & postest & No & Name & Pretest & postest \\
\hline $\mathbf{1}$ & S1 & 63.5 & 72 & 1 & S1 & 62 & 71.5 \\
\hline $\mathbf{2}$ & S2 & 62.5 & 62.5 & 2 & S2 & 49 & 62 \\
\hline
\end{tabular}




\begin{tabular}{|c|c|c|c|c|c|c|c|}
\hline 3 & S3 & 53 & 64 & 3 & S3 & 48 & 64 \\
\hline 4 & S4 & 51.5 & 88.5 & 4 & $\mathrm{~S} 4$ & 51.5 & 88.5 \\
\hline 5 & S5 & 49.5 & 85 & 5 & S5 & 50.5 & 80 \\
\hline 6 & S6 & 58.5 & 81.5 & 6 & S6 & 45.5 & 81.5 \\
\hline 7 & S7 & 63.5 & 90 & 7 & S7 & 55 & 67 \\
\hline 8 & S8 & 63 & 90.5 & 8 & S8 & 57 & 66.5 \\
\hline 9 & S9 & 63 & 75 & 9 & S9 & 58 & 75 \\
\hline 10 & $\mathrm{~S} 10$ & 62 & 90 & 10 & S10 & 45 & 66 \\
\hline 11 & S11 & 62 & 91 & 11 & S11 & 46.5 & 66.5 \\
\hline 12 & $\mathrm{~S} 12$ & 60.5 & 74.5 & 12 & S12 & 60 & 74.5 \\
\hline 13 & S13 & 60.5 & 72 & 13 & S13 & 50.5 & 72 \\
\hline 14 & $\mathrm{~S} 14$ & 50.5 & 73 & 14 & S14 & 52.5 & 73 \\
\hline 15 & S15 & 48.5 & 70 & 15 & S15 & 61 & 65 \\
\hline 16 & S16 & 48.5 & 73 & 16 & S16 & 62.5 & 73 \\
\hline 17 & S17 & 49 & 84 & 17 & S17 & 60.5 & 84 \\
\hline 18 & $\mathrm{~S} 18$ & 51 & 83.5 & 18 & S18 & 48 & 83.5 \\
\hline 19 & S19 & 51 & 93 & 19 & S19 & 43.5 & 68.5 \\
\hline 20 & S20 & 51 & 94 & 20 & S20 & 51.5 & 61 \\
\hline 21 & S21 & 50.5 & 90.5 & 21 & S21 & 48.5 & 74 \\
\hline 22 & $\mathrm{~S} 22$ & 51 & 72 & 22 & $\mathrm{~S} 22$ & 60 & 72 \\
\hline 23 & S23 & 57.5 & 72.5 & 23 & S23 & 61.5 & 67 \\
\hline 24 & S24 & 54.5 & 72 & 24 & S24 & 61.5 & 72 \\
\hline 25 & $\mathrm{~S} 25$ & 59 & 81.5 & 25 & $\mathrm{~S} 25$ & 56 & 81.5 \\
\hline 26 & S26 & 62.5 & 62.5 & 26 & S26 & 60.5 & 62.5 \\
\hline 27 & S27 & 61 & 95 & 27 & S27 & 50 & 66 \\
\hline 28 & $\mathrm{~S} 28$ & 61.5 & 94.5 & 28 & S28 & 50.5 & 62.5 \\
\hline 29 & S29 & 62 & 95.5 & 29 & S29 & 43 & 60 \\
\hline 30 & $\mathrm{~S} 30$ & 62 & 62 & 30 & S30 & 42.5 & 62 \\
\hline 31 & S31 & 49 & 82.5 & 31 & S31 & 50 & 82.5 \\
\hline 32 & S32 & 48 & 82 & 32 & S32 & 51.5 & 82 \\
\hline 33 & S33 & 43 & 82.5 & 33 & S33 & 50.5 & 82.5 \\
\hline 34 & S34 & 44.5 & 85 & 34 & S34 & 51 & 63 \\
\hline
\end{tabular}

Descriptive statistic is a wide variety of techniques that allow us to describe the general characteristic of the data we collect. The result of the test can be seen below as follow:

Table 2.

Descriptive Statistic of Experimental Class and Control Class

\begin{tabular}{|c|c|c|c|c|c|c|c|}
\hline Variab & & \multicolumn{3}{|c|}{ Experimental Class } & \multicolumn{3}{|c|}{ Control class } \\
\hline \multirow{4}{*}{$\begin{array}{l}\text { Writin } \\
\text { g skill }\end{array}$} & & e test $^{\text {Pr }}$ & t test $^{\text {Pos }}$ & -Gain $^{N}$ & e test $^{\text {Pr }}$ & t test $^{\text {Pos }}$ & $\begin{array}{l}\mathrm{N} \\
\text {-Gain } \\
\end{array}$ \\
\hline & $\mathbf{N}$ & 34 & 34 & 34 & 34 & 34 & 34 \\
\hline & $\begin{array}{ll} & \text { Mea } \\
\text { n } & \\
\end{array}$ & 55.05 & 80.76 & 0.56 & 51.81 & 70.88 & 0.38 \\
\hline & $\operatorname{Max}^{X}$ & 64 & 96 & 0.88 & 63 & 89 & 0.71 \\
\hline
\end{tabular}




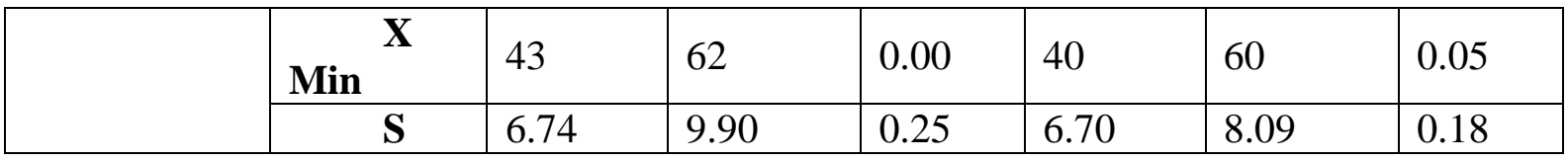

Based on table above, the $\mathrm{N}$ in experimental class was 34 students. The minimum score of pretest in this class was 43, while the maximum score was 64 . The mean score was 55.05, and Std. Deviation was 6.74. Meanwhile the $\mathrm{N}$ in control class was 34 students, the minimum score was 40 and the maximum score was 63 . The mean score was 51.81 with 6.70 for Std. Deviation.

The table above showed, the minimum score of post-test in experimental class is 62 , the maximum score is 96 and the mean is 80.76 with Std. Deviation is 9.90. Meanwhile in control class, the minimum score is 60 , the maximum score is 89 and the mean is 70.88 with 8.09 for Std. Deviation. Besides, the $\mathrm{N}$ of each class is 34 students.

So, the improvement of experimental class was higher than control class because the mean of $\mathrm{N}$-gain in experimental class was 0.6 , it was based on the classification according to (Archambaut (2008) in Tropika et al., 2015) as follow:

$$
\mathrm{N}-\text { Gain }=\frac{\text { Score of posttest }- \text { score of pretest }}{\text { Max score }- \text { score of pretest }} \quad \mathrm{X} 100
$$

Table 3.

Classification of N-Gain

\begin{tabular}{|l|l|}
\hline Mean of N-Gain & Classification \\
\hline N-gain $>0.7$ & High \\
\hline $0.3>$ N-Gain $<0.7$ & Medium \\
\hline $0.3<$ N-Gain & Low \\
\hline
\end{tabular}

Table 4

Test Normality of Pretest and Postest

\begin{tabular}{|l|l|r|r|r|r|r|r|}
\hline \multicolumn{2}{|c|}{ Tests of Normality } \\
\hline \multirow{2}{*}{} & \multicolumn{2}{|c|}{ Kolmogorov-Smirnov } & \multicolumn{3}{c|}{ Shapiro-Wilk } \\
\cline { 2 - 8 } & Statistic & Df & \multicolumn{1}{|c|}{ Sig. } & Statistic & df & Sig. \\
\hline PRETEST & Experimental & .192 & 34 & .003 & .881 & 34 & .002 \\
\cline { 2 - 8 } & Control & .172 & 34 & .012 & .927 & 34 & .026 \\
\hline Posttest & Experiment & .127 & 34 & .181 & .933 & 34 & .039 \\
\cline { 2 - 8 } & Control & .154 & 34 & .040 & .928 & 34 & .028 \\
\hline
\end{tabular}

From the data above, we see in the Shapiro-Wilk column and it can be seen that the value of Sig. for pretest of experimental class was 0.002 and pretest of control class was 0.026 . 
Moreover, the value of Sig. for posttest of experimental class was 0.039 and posstest of control class was 0.028 . It means the data is un-normally distributed, because the Sig. value is low than 0.05. Therefore, the next step is Mann-Whitney test.

Table 5.

Test Nonparametric (Mann Whitney U test) Pretest and Postest

\begin{tabular}{|c|c|c|c|c|}
\hline \multicolumn{5}{|c|}{ Test Statistics $^{a}$} \\
\hline & & & PRET & POST \\
\hline & & & EST & EST \\
\hline \multirow{2}{*}{\multicolumn{3}{|c|}{ Mann-Whitney U }} & 420.50 & 302.50 \\
\hline & & & 0 & 0 \\
\hline \multirow{2}{*}{\multicolumn{3}{|c|}{ Wilcoxon W }} & 1015.5 & 1005.5 \\
\hline & & & 00 & 00 \\
\hline \multicolumn{3}{|l|}{ Z } & -1.934 & -4.134 \\
\hline \multicolumn{3}{|l|}{ Asymp. Sig. (2-tailed) } & .053 & .000 \\
\hline \multirow{3}{*}{$\begin{array}{l}\text { Monte Carlo Sig. (2- } \\
\text { tailed) }\end{array}$} & \multicolumn{2}{|l|}{ Sig. } & $.057^{b}$ & $.000^{\mathrm{b}}$ \\
\hline & \multirow{2}{*}{$\begin{array}{l}95 \% \text { Confidence } \\
\text { Interval }\end{array}$} & .000 & .053 & .000 \\
\hline & & .000 & .062 & .000 \\
\hline \multirow{3}{*}{$\begin{array}{l}\text { Monte Carlo Sig. (1- } \\
\text { tailed) }\end{array}$} & \multicolumn{2}{|l|}{ Sig. } & $.028^{\mathrm{b}}$ & $.000^{\mathrm{b}}$ \\
\hline & \multirow{2}{*}{$\begin{array}{l}95 \% \text { Confidence } \\
\text { Interval }\end{array}$} & .000 & .025 & .000 \\
\hline & & .000 & .032 & .000 \\
\hline
\end{tabular}

The table above showed that the data Asymp. Sig. (2-tailed) is 0.053 in pretest were higher than 0.05. It means that there was not significance different between experimental class and control class. That is because the treatment have not giving to each classes. Moreover, we could see this fact from the test statistic in the table above of Asymp Sig. (2-tailed) in postest. The table of postest showed that the significant value was lower than 0.05 , so it can be concluded that the students basic in writing skill there were significantly different between both of the class. This means that $\mathrm{HO}$ rejected and $\mathrm{H}_{1}: \mathcal{M}_{1}=\mathcal{M}_{6}\left(\mathrm{H}_{1}\right.$ accepted $)$ it shows that make a match method is better than the teacher method.

\section{Discussion}

From the data above, the researchers used make a match method. Before conducting the treatment, pretest was given to both of class. The data in experimenttal class were: the highest score was 64 , the lowest score was 43 , and the mean score was 55.05. The data in control class were: the highest score was 63 the lowest score was 40, and the mean was 51.81 The data showed that the students' score still low. 
After gave pretest, the researchers carried out the normality test. The result of normality of pretest was the Sig. of pretest experimental class was 0.002 and control class were 0.026 , it means both of them less than 0.050 , it means that the data was un-normal distributed. So, the next step carried out Mann-Whitney. The result of Mann-Whitney was 0.053 it was higher than 0.05. it can be conclude that $\mathrm{H}_{0}(\mathrm{H}$-null) hypothesis was accepted. In other words, there is no difference ability between experimental class and control class.

After conducting the treatment, the researcher gave post-test to students in order to obtain their score. The data had been obtained in post-test of experimental class were: the highest score was 96, the lowest score was 62, and the mean score was 80.76. Post-test of control class were: the highest score was 89 , the lower score was 60 , and the mean score was 70.88 . The data showed that students' score in experimental class highest than control class. It means that make a match method was effective to be applied in teaching and learning process, especially in writing descriptive text.

Then, the researchers carried out the normality of posttest. The result of normality of post-test was not normal because Sig. of experimental and control class were lower than index 0.05. it means that the data was not normal. So, he next step was Mann Whitney U test. The result is 0.00 , it was lower than index 0.05 . it means that $\mathrm{H}_{\mathrm{o}}$ was rejected. In other words there is a significant difference in students' score of writing recount text. So there is significant differences between make a match method and conventional method in writing descriptive text.

\section{CONCLUSION}

From the discussion above, it can be concluded that using of Make a Match method is more effective because Make a Match method can be improved the students writing skill especially in descriptive text. The data had been obtained in post-test of experimental class were: the highest score was 96, the lowest score was 62, and the mean score was 80.50. Post-test of control class were: the highest score was 89 , the lower score was 60 , and the mean score was 71.54. It can be seen from the data showed that students' score in experimental class was highest than control class. It means that using make a match method was effective, easier, and more understable to be applied in teaching and learning process, especially in writing descriptive text.

\section{ACKNOWLEDGMENTS}

Alhamdulillahirabbil'alamin, praise and thank you to Allah SWT, the Most Gracious, and Most Merciful. Praise God for the blessings given to the authors so that can complete this article.

\section{REFERENCES}

Apsari, Y. (2018). Reflective Reading Journal In Teaching Writing. Indonesian Efl Journal, 4(2), 39-47.

Apuke, O. D. (2017). Quantitative Research Methods : A Synopsis Approach. Kuwait Chapter Of Arabian Journal Of Business And Management Review, 6(11), 40-47. Https://Doi.Org/10.12816/0040336

Lailatul Husna, Zainil, Y. R. (2013). An Analysis Of Students' Writing Skill In Descriptive Text At Grade X1 Ipa 1 Of Man 2 Padang. An Analysis Of Students' Writing Skill In Descriptive Text At Grade X1 Ipa 1 Of Man 2 Padang, 1, 1-16.

Paltridege, B. (1996). 2 Paltridge Genre Text Type_5. 50(July), 237-243.

Santosa, I., \& Andriyadi. (N.D.). The Use Of My Dictionary Application To Improve Students 
'Vocabulary Mastery. 35-42.

Siti, M., \& Suprijadi, D. (2015). Eltin Journal Vol 3/1, April 2015. Elitn Journal, 3(April), 3852.

Tropika, J. E., Magister, P., Biologi, P., Kuala, U. S., Biologi, P. P., Kuala, U. S., ... Kuala, U. S. (2015). Rosdiana Meliana Situmorang. 3, 87-90.

Wastawan, K., Sutarsyah, C., \& Sudirman, S. (2014). Increasing Students' Reading Comprehension Through Make A Match Type Of Cooperative Learning At First Grade Of Sma. U-Jet, 3(2), 0-11.

Yulianti, S., Nuraeni, S., \& Parmawati, A. (2019). Improving Students'writing Skill Using Brainswriting Strategy. Project (Professional Journal Of English Education), 2(5), 714721. 